\title{
Greenhouse gas metabolism in Nordic boreal lakes
}

\author{
Hong Yang • Tom Andersen • Peter Dörsch • \\ Koji Tominaga $\cdot$ Jan-Erik Thrane $\cdot$ Dag O. Hessen
}

Received: 13 May 2015/Accepted: 3 October 2015/Published online: 30 October 2015

(C) The Author(s) 2015. This article is published with open access at Springerlink.com

\begin{abstract}
Boreal lakes are important net sources of greenhouse gases (GHGs). In this study we analyzed concentrations of $\mathrm{CO}_{2}, \mathrm{CH}_{4}, \mathrm{~N}_{2} \mathrm{O}$ as well as $\mathrm{O}_{2}, \mathrm{~N}_{2}$ and argon (Ar) from the epilimnion of 75 boreal lakes covering gradients in total organic carbon (TOC), phosphorus $(\mathrm{P})$ and nitrogen $(\mathrm{N})$ deposition. The Ar-corrected gas saturation deficit was used as a proxy of net metabolic changes from spring overturn to mid-summer sampling (all lakes were dimictic). Emission fluxes were calculated for
\end{abstract}

Responsible Editor: Jennifer Leah Tank.

Electronic supplementary material The online version of this article (doi:10.1007/s10533-015-0154-8) contains supplementary material, which is available to authorized users.

H. Yang $(\varangle) \cdot$ T. Andersen $\cdot$ K. Tominaga .

J.-E. Thrane · D. O. Hessen

Section for Aquatic Biology and Toxicology (AKVA), Department of Biosciences, University of Oslo, 0316 Oslo, Norway

e-mail: hongyanghy@gmail.com

H. Yang · K. Tominaga - J.-E. Thrane $\cdot$ D. O. Hessen Department of Biosciences, Centre for Ecological and Evolutionary Synthesis (CEES), University of Oslo, 0316 Oslo, Norway

P. Dörsch

Department of Environmental Sciences, Norwegian University of Life Sciences, 1432 Ås, Norway
$\mathrm{CO}_{2}, \mathrm{CH}_{4}$ and $\mathrm{N}_{2} \mathrm{O}$ based on partial pressure, water temperature and wind speed. Gas concentrations, actual and Ar-corrected, were related to lakespecific properties. TOC was the main predictor of $\mathrm{CO}_{2}$ concentrations and fluxes, followed by total $\mathrm{P}$, while total $\mathrm{P}$ and chlorophyll $a$ governed $\mathrm{CH}_{4}$ concentrations and fluxes. Nitrogen $\left(\mathrm{NO}_{3}{ }^{-}\right.$or total $\mathrm{N})$ were key predictors of $\mathrm{N}_{2} \mathrm{O}$ concentrations and fluxes, followed by total $\mathrm{P}$. Altitude, area and depth were not strong predictors of $\mathrm{CO}_{2}, \mathrm{CH}_{4}$ and $\mathrm{N}_{2} \mathrm{O}$ concentrations and fluxes, likely because only lakes with an area of $>1 \mathrm{~km}^{2}$ were included. $\mathrm{CO}_{2}$ molar concentrations were negatively correlated with $\mathrm{O}_{2}$ concentrations, while the slope of $\mathrm{CO}_{2}$ concentration to $\mathrm{Ar}$ corrected $\mathrm{O}_{2}$ deficit was 1.039. Together with the poor correlation between area-specific primary production and $\mathrm{CO}_{2}$ as well as $\mathrm{O}_{2}$, this suggests that these gases are mostly affected by catabolic processes and probably photo-oxidation in these nutrient-poor, boreal lakes investigated in this study. Increasing inputs of TOC (i.e. lake "browning") is likely to promote the net heterotrophy and hence emissions of all GHGs, while elevated $\mathrm{N}$ deposition in particular may cause elevated emissions of $\mathrm{N}_{2} \mathrm{O}$.

Keywords Carbon dioxide $\left(\mathrm{CO}_{2}\right) \cdot$ Methane $\left(\mathrm{CH}_{4}\right)$. Nitrous oxide $\left(\mathrm{N}_{2} \mathrm{O}\right) \cdot$ Metabolism $\cdot$ Boreal lakes 


\section{Introduction}

Inland waters are more important in the global carbon (C) cycle than generally perceived; they serve a dual role by sequestering $\mathrm{C}$ for burial in sediments while serving as conduits of the greenhouse gases (GHGs) $\mathrm{CO}_{2}, \mathrm{CH}_{4}$ and $\mathrm{N}_{2} \mathrm{O}$ to the atmosphere (Bastviken et al. 2004a; Cole et al. 1994; Hessen et al. 1990; Tranvik et al. 2009; Yang et al. 2008). Most effort has been devoted to the $\mathrm{CO}_{2}$ production in lakes, and in general lakes are net heterotrophic being strongly supersaturated with $\mathrm{CO}_{2}$ (Cole et al. 1994; Kling et al. 1992). This holds particularly for lakes with high concentrations of dissolved organic matter (DOM) or total organic carbon (TOC) (Jansson et al. 2007; Larsen et al. 2011a; Sobek et al. 2007). Kortelainen et al. (2013) found a $\mathrm{C}$ evasion to accumulation ratio ranging from 4 to 86 (average 30) in TOC rich lakes. Such lakes dominate the boreal biome of the northern hemisphere and typically are important conduits of GHGs. This is mostly because in-lake metabolic processes by heterotrophic bacteria and methanogenic archaea convert allochthonous organic matter to $\mathrm{CO}_{2}$ and $\mathrm{CH}_{4}$ (Bastviken et al. 2004b). Generally, these small lakes show disproportionately high emissions per surface area owing to their high concentrations of TOC and anoxic deep-waters (Bastviken et al. 2004a).

A number of studies have addressed the major determinants of $\mathrm{CO}_{2}$ and $\mathrm{CH}_{4}$ concentrations and export in and from lakes, and found lake productivity to be the major driver, ultimately controlled by phosphorus $(\mathrm{P})$ content, TOC concentration and lake morphometry (Juutinen et al. 2009; Yang et al. 2011). High nutrient levels promote autochthonous primary production which provides substrate for methanotrophs (Huttunen et al. 2003a; Schwarz et al. 2008; West et al. 2012). High primary production also increases the hypolimnetic respiration and sediment anoxia that may result in elevated emissions of $\mathrm{CO}_{2}$ and $\mathrm{CH}_{4}$. Alternatively, inputs of inorganic $\mathrm{C}$ linked to catchment properties may play a major role in $\mathrm{CO}_{2}$ release (Kankaala et al. 2013; McDonald et al. 2013).

Lakes may also be a net-source for $\mathrm{N}_{2} \mathrm{O}$, but there are few estimates for $\mathrm{N}_{2} \mathrm{O}$ dynamics in boreal regions. As an intermediate of denitrification, $\mathrm{N}_{2} \mathrm{O}$ should a priori be expected to depend on organic carbon, oxygen availability, temperature and nitrate concentration, which were shown to be the major predictors of $\mathrm{N}_{2} \mathrm{O}$ in previous surveys of temperate lakes
(Huttunen et al. 2003b; Kortelainen et al. 2013; Liikanen et al. 2003; Tremblay et al. 2005), pointing to elevated $\mathrm{N}$ deposition and warming as future drivers for $\mathrm{N}_{2} \mathrm{O}$-emissions from boreal lakes.

Concentrations and fluxes of $\mathrm{CO}_{2}, \mathrm{CH}_{4}$ and $\mathrm{N}_{2} \mathrm{O}$ in lakes are dynamic and vary with depth and season (Casper et al. 2000; Huttunen et al. 2003a; Riera et al. 1999; Xing et al. 2005). The major drivers of gas dynamics are related to metabolic processing of organic material, and subsequent solubility and gas diffusion.

Boreal lakes often have high area-specific GHG emissions (e.g. Bastviken et al. 2011; Raymond et al. 2013). Lake metabolism and hence the concentrations of $\mathrm{CO}_{2}, \mathrm{CH}_{4}$ and $\mathrm{N}_{2} \mathrm{O}$, their seasonal dynamics and emission are primarily influenced by lake morphometry and parameters governing primary and secondary productivity (e.g. Huttunen et al. 2003a; Juutinen et al. 2009; Larmola et al. 2004). Typically, concentrations of total $\mathrm{P}$ (TP) regulate the primary productivity, while allochthonous input of TOC stimulates production and respiration of heterotrophic bacteria (Berggren et al. 2009). The role of colored TOC is at least twofold, since it not only fuels productivity of heterotrophic bacteria, but also reduces primary production to due light attenuation (Jones et al. 2012; Seekell et al. 2015; Thrane et al. 2014). Dissolved organic matter, of which TOC constitutes a major pool, may however also be a source of TP and total N (TN) in pristine, boreal lakes (Kortelainen et al. 2006a). Both high autotrophic and heterotrophic productivity may generate hypolimnetic oxygen deficits or anoxia, thereby strongly affecting the gas concentrations and emissions (Hessen and Nygaard 1992; Huttunen et al. 2003a; Juutinen et al. 2009; Larmola et al. 2004). Hence, the net effect of autotrophic and heterotrophic productivity, or the role of TOC versus TP, on gas concentrations and emissions are not always straightforward.

Most studies in boreal lakes have addressed one or two GHGs (e.g. Demarty et al. 2011; Kankaala et al. 2013; Kortelainen et al. 2006b; Lemon and Lemon 1981; Ojala et al. 2011; Tremblay et al. 2005) (Table 1), while studies addressing all three biogenic GHGs $\left(\mathrm{CO}_{2}, \mathrm{CH}_{4}, \mathrm{~N}_{2} \mathrm{O}\right)$ are very limited (Huttunen et al. 2003a; Tremblay et al. 2005).

To reveal the major drivers of concentrations and emissions of these gases, we measured epilimnetic concentrations of $\mathrm{CO}_{2}, \mathrm{CH}_{4}, \mathrm{~N}_{2} \mathrm{O}, \mathrm{N}_{2}, \mathrm{O}_{2}$ and Argon 


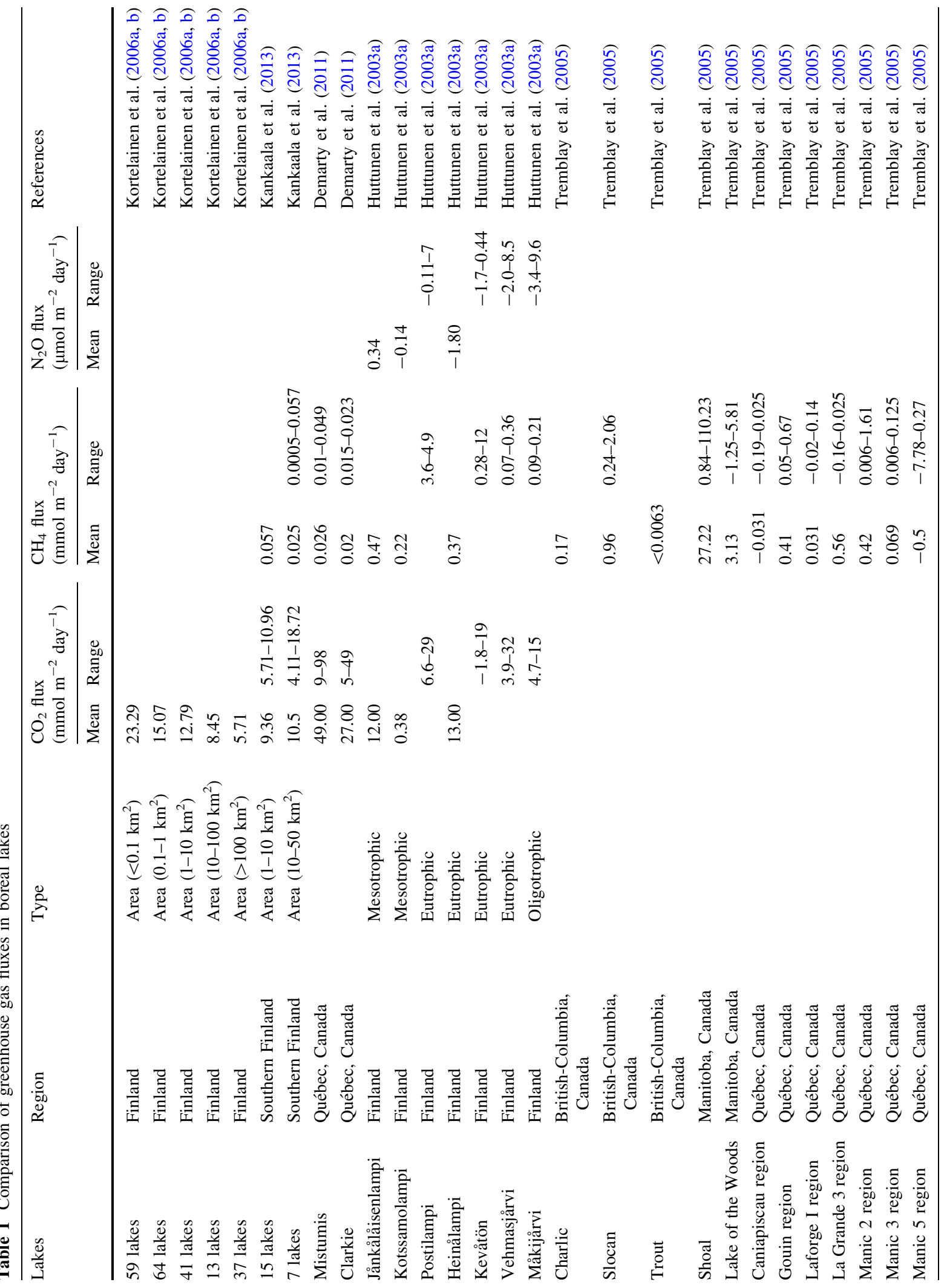




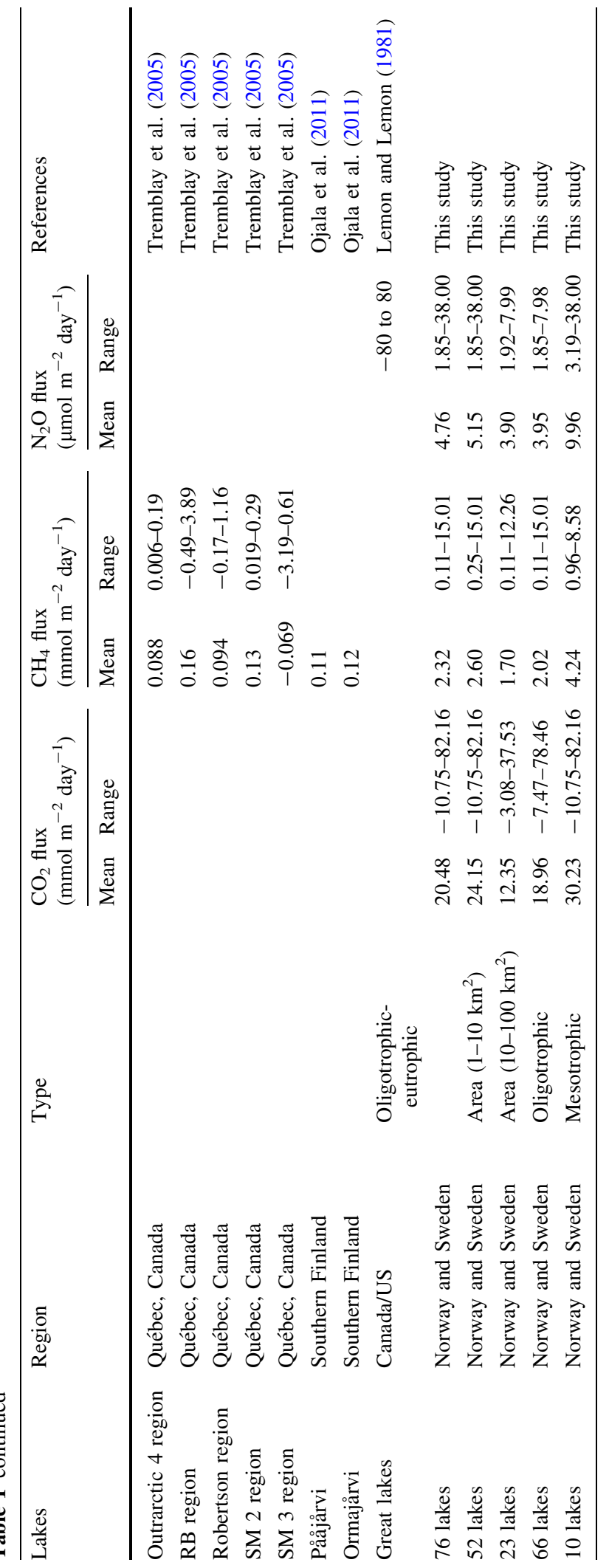


(Ar) in a synoptic survey covering 75 dimictic, boreal lakes in Norway and Sweden, with surface areas $>1 \mathrm{~km}^{2}$ and low to intermediate productivity. Exchange fluxes at the interface between water and atmosphere of Ar are controlled mainly by advection and turbulent mixing. Ar can thus serve as an inert tracer of these processes (Schwarzenbach et al. 2005; Tomonaga et al. 2012), and many studies report close agreement of dissolved $\mathrm{Ar}$ in water and expected atmospheric equilibrium concentration (e.g. Aeschbach-Hertig et al. 1999; Craig et al. 1992; Peeters et al. 1997; Tomonaga et al. 2012; Wilkinson et al. 2015). On the contrary, $\mathrm{O}_{2}$ and the GHGs $\mathrm{CO}_{2}, \mathrm{CH}_{4}$ and $\mathrm{N}_{2} \mathrm{O}$ are also affected by biogeochemical processes, for example photosynthesis, respiration, methanogenesis, methanotrophy, nitrification, and denitrification (e.g. Schwarzenbach et al. 2005). Ar, being biologically inert, may thus serve as an ideal tool for normalizing concentrations of other gases, yet it has so far rarely been applied in limnological studies (Craig et al. 1992; Tomonaga et al. 2012; Wilkinson et al. 2015). In this study, we make the first attempt to calculate $\mathrm{Ar}$ normalized gas saturation for $\mathrm{O}_{2}, \mathrm{CO}_{2}, \mathrm{~N}_{2} \mathrm{O}$ and $\mathrm{CH}_{4}$ and use the relative deviation from Ar-equilibrium at a late summer sampling as a proxy for cumulative net metabolic activity since spring overturn in boreal lakes. In addition, we estimated the GWP of these three GHGs, $\mathrm{CO}_{2}, \mathrm{CH}_{4}$ and $\mathrm{N}_{2} \mathrm{O}$ in $\mathrm{CO}_{2}$ equivalents and analysed the effect of lake productivity, browning and other factors on the GWP of boreal lakes.

\section{Materials and methods}

\section{Sampling programme}

The sampled lakes spanned a wide range of physical, chemical and biological properties, but were primarily selected to span wide and orthogonal gradients in TOC and total phosphorus (TP). Existing data of the Norwegian and Swedish lake monitoring scheme (Solheim et al. 2008) and of the Northern European lake survey (Henriksen et al. 1998) were combined to generate a subset of lakes satisfying the following criteria: latitude $57-64^{\circ} \mathrm{N}$, altitude $<600 \mathrm{~m}$, surface area $>1 \mathrm{~km}^{2}, \quad \mathrm{pH}>5, \quad \mathrm{TP}<30 \mu \mathrm{g} \mathrm{L}^{-1}, \quad$ and TOC $<30 \mathrm{mg} \mathrm{L}^{-1} .75$ lakes were chosen from this subset by stratified randomization to ensure best possible coverage and orthogonality with respect to concentrations of TOC and TP (Fig. 1). The lakes were sampled by hydroplane during July and August 2011.

Composite samples ( $15 \mathrm{~L}$ in total) from 0 to $5 \mathrm{~m}$ were taken with an integrating water sampler (HydroBIOS, Germany) in the central part of each lake during daytime. Water temperature was measured using XRX-620 10-channel CTD (RBR Ltd., Canada). High-resolution vertical temperature profiles indicated that the thermocline was deeper than $5 \mathrm{~m}$ in all lakes (Fig. 2), and that, accordingly, the integrated 0-5 m samples could be considered representative of the entire mixed layers of the lakes. Water transparency was measured by lowering a white Secchi disc and recording the depth where it was no longer visible.

\section{Chemical analysis}

Concentrations of TP, TN and TOC were measured both at the accredited laboratories at the Norwegian Institute for Water Research (NIVA) and at the University of Oslo (UiO). TP was measured on an auto-analyzer as phosphate after wet oxidation with peroxodisulfate in both laboratories. TN was measured by detecting nitrogen monoxide by chemiluminescence using a TNM-1 unit attached to the Shimadzu TOC-VWP analyzer (UiO), or detection of nitrate after wet oxidation with peroxodisulfate in a segmented flow autoanalyzer (NIVA). Since the results from the two laboratories were very similar, results were averaged for the following analysis.

Gas analysis and Ar-normalization

Water from the integrated water sample (same depth interval as for the other parameters) was gently let into $120 \mathrm{~mL}$ glass serum-vials without bubbling, fixed with $0.2 \% \mathrm{HgCl}_{2}$ and sealed with gas-tight butyl rubber stoppers. The samples were stored cold $\left(4{ }^{\circ} \mathrm{C}\right)$ in the dark prior to analysis. Concentrations of $\mathrm{Ar}, \mathrm{O}_{2}$, $\mathrm{N}_{2}, \mathrm{~N}_{2} \mathrm{O}, \mathrm{CO}_{2}$ and $\mathrm{CH}_{4}$ were determined by headspace technique. For this, bottles were allowed to reach room temperature before backfilling them with $20-30 \mathrm{~mL}$ Helium (He) while removing a corresponding volume of water from the bottle. The bottles were shaken horizontally at $150 \mathrm{rpm}$ for $2 \mathrm{~h}$ to equilibrate gases between sample and headspace. The temperature during shaking was recorded by a data logger. 
Fig. 1 Location and total organic carbon (TOC) concentration of the surveyed lakes in Norway and Sweden
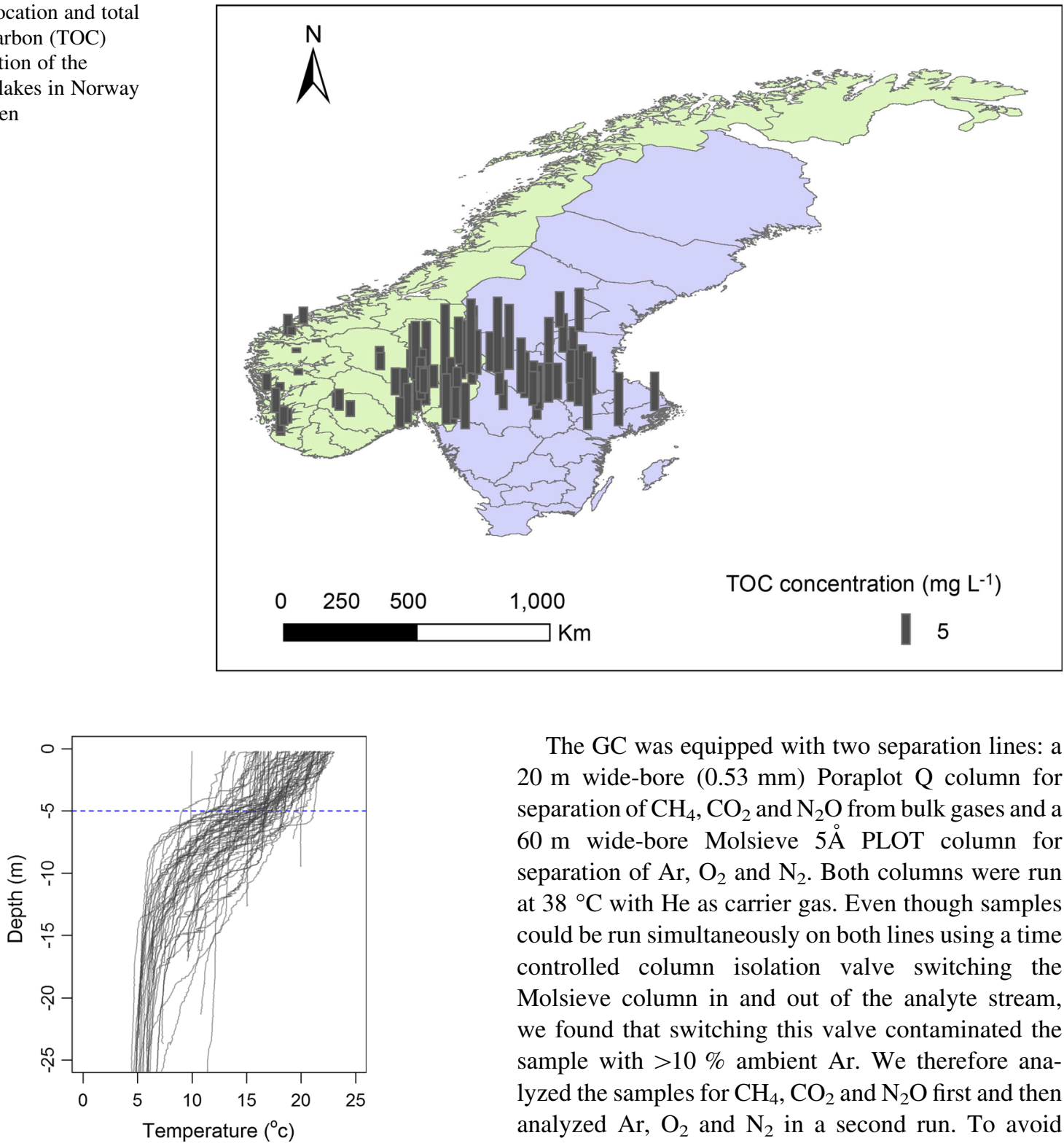

Fig. 2 Temperature profiles in summer in the surveyed lakes in Norway and Sweden

Immediately after shaking, the bottles were placed in an autosampler (GC-Pal, CTC, Switzerland) coupled to a gas chromatograph (GC) with He back-flushing (Model 7890A, Agilent, Santa Clara, CA, US). Headspace gas was sampled (app. $2 \mathrm{~mL}$ ) by a hypodermic needle connected to a peristaltic pump (Gilson Minipuls 3), which connected the autosampler with the $250 \mu \mathrm{L}$ heated sampling loop of the GC.
The GC was equipped with two separation lines: a $20 \mathrm{~m}$ wide-bore $(0.53 \mathrm{~mm})$ Poraplot $\mathrm{Q}$ column for separation of $\mathrm{CH}_{4}, \mathrm{CO}_{2}$ and $\mathrm{N}_{2} \mathrm{O}$ from bulk gases and a $60 \mathrm{~m}$ wide-bore Molsieve $5 \AA$ PLOT column for separation of $\mathrm{Ar}, \mathrm{O}_{2}$ and $\mathrm{N}_{2}$. Both columns were run at $38{ }^{\circ} \mathrm{C}$ with $\mathrm{He}$ as carrier gas. Even though samples could be run simultaneously on both lines using a time controlled column isolation valve switching the Molsieve column in and out of the analyte stream, we found that switching this valve contaminated the sample with $>10 \%$ ambient Ar. We therefore analyzed the samples for $\mathrm{CH}_{4}, \mathrm{CO}_{2}$ and $\mathrm{N}_{2} \mathrm{O}$ first and then analyzed $\mathrm{Ar}, \mathrm{O}_{2}$ and $\mathrm{N}_{2}$ in a second run. To avoid pressure drop in the bottles between the runs, an equivalent amount of He was automatically pumped back from a He line located at the waste end of the GC by reversing the peristaltic pump, thereby diluting the headspace (for details, see Molstad et al. 2007).

$\mathrm{N}_{2} \mathrm{O}$ was measured on an electron capture detector run at $375{ }^{\circ} \mathrm{C}$ with $17 \mathrm{~mL} \min ^{-1} \mathrm{Ar}: \mathrm{CH}_{4}$ (90:10 vol\%) as makeup gas. $\mathrm{CH}_{4}$ was analyzed by a flame ionization detector, while all other gases were measured by a thermal conductivity detector (TCD). Certified standards of $\mathrm{CO}_{2}, \mathrm{~N}_{2} \mathrm{O}$ and $\mathrm{CH}_{4}$ in $\mathrm{He}$ were used for calibration (AGA, Germany), whereas $\mathrm{N}_{2}, \mathrm{O}_{2}$, 
and $\mathrm{Ar}$ were calibrated against air. The analytical precision for all gases was better than $1 \%$. Relative headspace concentrations (corrected for dilution in the second run) were used to calculate the concentrations of the dissolved gases in the samples using temperature-dependent Henry's law constants provided by Wilhelm et al (1977) and the average temperature recorded during the $2 \mathrm{~h}$ equilibration period.

$\mathrm{O}_{2}$ was measured independently using XRX-620 CTD equipped with a Rinko III fluorometric oxygen probe at $<5 \mathrm{~cm}$ vertical resolution and averaged over the same depth interval as the integrated water samples. The results correlated closely with those obtained from GC $\left(\mathrm{r}^{2}=0.63, p<0.001\right)$.

Dissolved gas concentrations in dimictic lakes in summer may be seen as the net result of all metabolically and physically driven changes since the (possibly incomplete) circulation at spring overturn. We thus calculated saturations relative to atmospheric equilibrium for all gases using in situ measurement of water temperature. Henry's law constants (taken from Wilhelm et al. 1977) were recalculated from $25^{\circ} \mathrm{C}$ to in situ water temperature using the Clausius-Clapeyron equation with gas-specific enthalpies of solution given by Wilhelm et al (1977). Equilibrium concentrations were then calculated as Henry's law constants multiplied by average atmospheric pressures of individual gases.

$\mathrm{Ar}$ in water is governed solely by physical processes such as diffusion and partition between different phases, while $\mathrm{O}_{2}, \mathrm{~N}_{2}$ and the GHGs $\mathrm{CO}_{2}$, $\mathrm{CH}_{4}$ and $\mathrm{N}_{2} \mathrm{O}$ are controlled by both physical and biogeochemical processes (Aeschbach-Hertig et al. 1999). We thus used the relative saturation of this noble gas to normalize the relative saturations of all other gases. This normalization corrects for incomplete atmospheric equilibration at spring overturn.

\section{GHG fluxes}

We calculated the greenhouse gas (GHG) partial pressures $\left(p \mathrm{CO}_{2}, p \mathrm{CH}_{4}, p \mathrm{~N}_{2} \mathrm{O}\right)$, and thereby estimated the flux using water temperatures and wind speeds. The mass transfer coefficient was estimated from local wind speed provided by the Norwegian Reanalysis Archive, a dynamical downscaling of ERA-40 (references are given in the Supplementary Material), and the Schmidt number (Cole and Caraco 1998; Johnson 2010; Wanninkhof 1992). Partial pressures were calculated from GHG concentration in the water and their Henry's law constants (Wanninkhof 1992), temperature adjusted according to Wilhelm et al. (1977). $\mathrm{CO}_{2}, \mathrm{CH}_{4}$ and $\mathrm{N}_{2} \mathrm{O}$ fluxes were then calculated as the product of the gas saturation deficit (difference between partial pressures) and the Schmidt number. It is noteworthy that the Schmidt number calculated by the method provided by Cole and Caraco (1998) gives a theoretical value, which may result in an underestimation of actual emissions because wind speeds at low convective mixing may play an important role (Read et al. 2012). For more details see equations in Supporting Information.

Global warming potentials (GWP, time horizon 100 year) for aggregate GHGs $\mathrm{CO}_{2}, \mathrm{CH}_{4}$, and $\mathrm{N}_{2} \mathrm{O}$ release from lake surfaces were calculated as $\mathrm{CO}_{2}$ mass equivalents using the latest IPCC report coefficients of 34 for $\mathrm{CH}_{4}$ and 298 for $\mathrm{N}_{2} \mathrm{O}$ (Myhre et al. 2013).

An array of correlation analyses was conducted for GHG $\left(\mathrm{CO}_{2}, \mathrm{CH}_{4}\right.$, and $\left.\mathrm{N}_{2} \mathrm{O}\right)$ concentrations, $\mathrm{Ar}$ normalized saturation and GWP with environmental variables in these lakes. As environmental variables we included lake altitude, lake area, lake depth at sampling point (a proxy for maximum depth), chlorophyll $a$ (Chl $a$ ), total organic carbon (TOC), total inorganic carbon (TIC), total phosphorus (TP), total nitrogen ( $\mathrm{TN}), \mathrm{NO}_{3}{ }^{-}$, Secchi depth, and area-specific primary production (PPA). In brief, the PPA estimates were calculated using a bio-optical model based on phytoplankton absorption, in situ irradiance, and the light dependent quantum yield of photosystem II. See Thrane et al. (2014) for details. All the statistical analyses were conducted using the software R (R Core Team 2014).

\section{Results}

Across all lakes, the mean surface molar concentrations of $\mathrm{N}_{2}$ and $\mathrm{O}_{2}$ were 577.5 and $285.6 \mu \mathrm{mol} \mathrm{L}^{-1}$, while average concentrations of $\mathrm{CO}_{2}, \mathrm{CH}_{4}$ and $\mathrm{N}_{2} \mathrm{O}$ were smaller with 47.0, 0.13 and $0.015 \mu \mathrm{mol} \mathrm{L}^{-1}$, respectively (Fig. 3). The mean concentration of Ar was $16.0 \mu \mathrm{mol} \mathrm{L}{ }^{-1}$. Concentrations of gases, particularly those of the GHGs, ranged widely across all lakes. Inert $\mathrm{Ar}$ and semi-inert $\mathrm{N}_{2}$ showed a relative smaller variability [coefficients of variation $(\mathrm{CV})=6.3$ and $7.3 \%$, while the variability was greater for $\mathrm{O}_{2}$ and $\mathrm{N}_{2} \mathrm{O}$ 

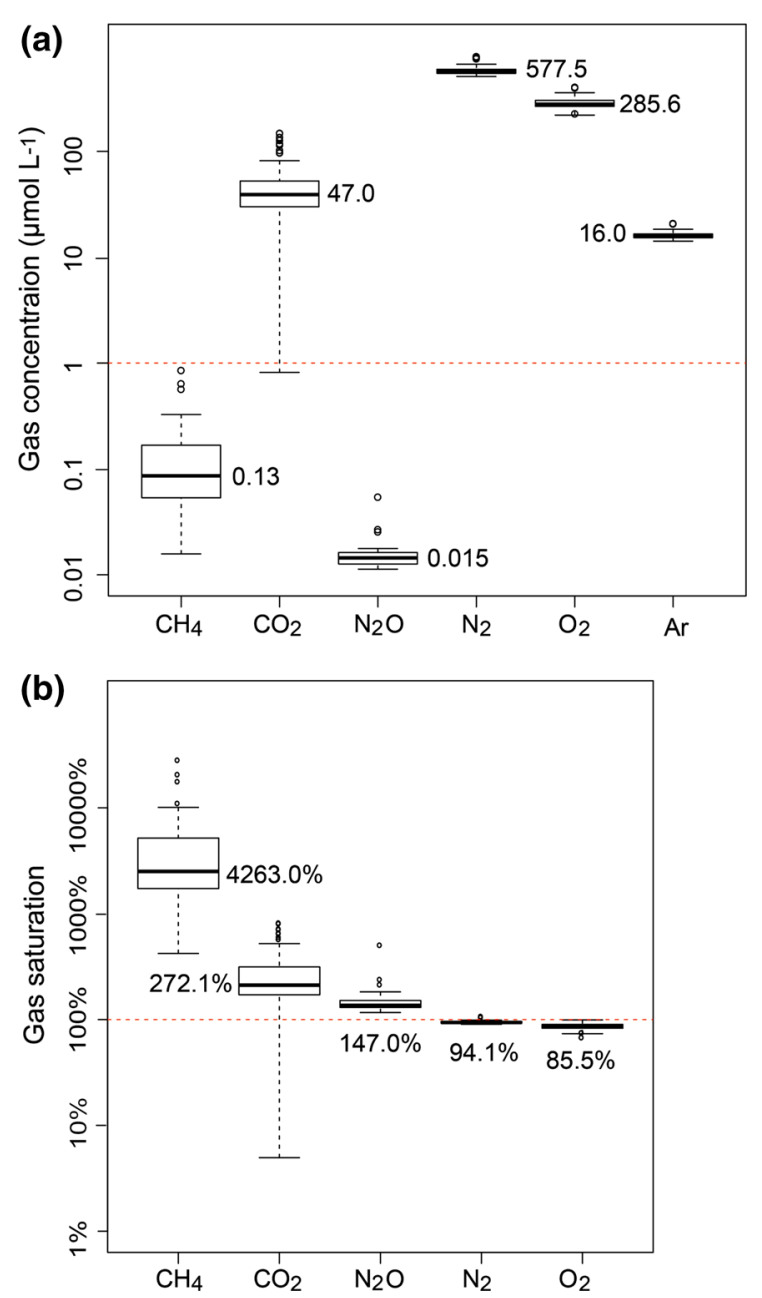

Fig. 3 Epilimnetic gas concentration (a) and Ar normalized gas saturation (b) of the surveyed lakes in Norway and Sweden. $Y$ axis is a 10-base logarithmic scale. The values are the means of gas concentrations or saturation in \%

$(\mathrm{CV}=11.7$ and $30.4 \%)$, and highest for $\mathrm{CO}_{2}$ and $\mathrm{CH}_{4}$ $(\mathrm{CV}=63.0$ and $100.5 \%)$. The Ar-corrected gas saturations increased from $\mathrm{O}_{2} \quad$ (mean $=85.5 \%$, $\mathrm{CV}=8.2 \%)$ and $\mathrm{N}_{2}($ mean $=94.1 \%, \mathrm{CV}=2.2 \%)$ to $\mathrm{N}_{2} \mathrm{O} \quad($ mean $=147.0 \%, \quad \mathrm{CV}=29.1 \%), \mathrm{CO}_{2}$ (mean $=272.1 \%, \quad \mathrm{CV}=63.1) \quad$ and $\quad \mathrm{CH}_{4}$ (mean $=4263 \%, \mathrm{CV}=106.5 \%$ ) (Fig. 3). Variations in GHG saturation among these lakes were much larger than those of $\mathrm{N}_{2}$ and $\mathrm{O}_{2}$.

Surface $\mathrm{CO}_{2}$ concentrations across lakes were significantly negatively correlated with surface $\mathrm{O}_{2}$ concentration $\left(\mathrm{r}^{2}=0.232, p<0.0001\right.$, Fig. $\left.4 \mathrm{c}\right)$. The slope of the $\mathrm{CO}_{2} / \mathrm{O}_{2}$ deficit relationship (mean $\pm \mathrm{SD}$, $1.039 \pm 0.630$ ) indicated that $\mathrm{CO}_{2}$ was produced at unit stoichiometry [respiratory quotient $(\mathrm{RQ})=1$ ] with $\mathrm{O}_{2}$ consumption by biological or photochemical oxidation of organic matter (Fig. 4d).

Secchi depths across lakes was negatively correlated with TOC $\left(\mathrm{r}^{2}=0.528, p<0.0001\right)$, less so with Chl $a\left(\mathrm{r}^{2}=0.164, p<0.01\right)$, yet these two parameters combined explained $>60 \%$ of Secchi depth variability arguing for keeping this variable in the analysis.

Using a range of the lake-specific parameters as explanatory variables (see "Materials and methods" section), we were able to explain $42-79 \%$ of the variance in surface gas concentrations, with the highest degree of explanation for $\mathrm{CO}_{2}$ concentrations and the lowest for $\mathrm{CH}_{4}$ concentrations (Table 2). The major explanatory variables for surface $\mathrm{CO}_{2}$ concentrations were TOC $\left(\mathrm{r}^{2}=0.221, p<0.001\right)$ and TP $\left(\mathrm{r}^{2}=0.117, p<0.01\right)$. Surface $\mathrm{CH}_{4}$ concentrations were best explained by Chl $a \quad\left(\mathrm{r}^{2}=0.304\right.$, $p<0.0001)$, TP $\left(\mathrm{r}^{2}=0.234, p<0.0001\right)$, total inorganic carbon (TIC) $\left(\mathrm{r}^{2}=0.169, p<0.01\right)$ and conductivity $\left(\mathrm{r}^{2}=0.124, p<0.01\right)$. For surface $\mathrm{N}_{2} \mathrm{O}$ concentrations, unsurprisingly TN $\left(\mathrm{r}^{2}=0.250\right.$, $p<0.0001)$ and $\mathrm{NO}_{3}{ }^{-}\left(\mathrm{r}^{2}=0.299, p<0.0001\right)$ were the main explanatory variables, accompanied by TP $\left(\mathrm{r}^{2}=0.301, p<0.0001\right), \mathrm{Chl} a\left(\mathrm{r}^{2}=0.120, p<0.01\right)$ and area-specific primary production (PPA) $\left(\mathrm{r}^{2}=0.142, p<0.001\right)$. Interestingly, PPA did not appear as a major determinant for surface $\mathrm{CO}_{2}$ concentrations $\left(\mathrm{r}^{2}=0.003, p=0.633\right)$ or for $\mathrm{O}_{2}$ concentrations $\left(r^{2}=0.018, p=0.249\right)$.

Lake morphometry and physical properties had no significant impact on GHG concentrations. For example, lake area $\left(\mathrm{r}^{2}=0.063, p=0.023\right)$, depth $\left(\mathrm{r}^{2}=0.061, p=0.011\right)$ and altitude $\left(\mathrm{r}^{2}=0.019\right.$, $p=0.188$ ) had little impact, yet depth gave a weak negative contribution to surface $\mathrm{CH}_{4}$ concentration. Likewise, temperature appeared as a minor contributor $\left(\mathrm{r}^{2}=0.020, p=0.258\right)$.

The average flux of $\mathrm{CO}_{2}$ was $20.48 \mathrm{mmol} \mathrm{m}^{-2}$ day $^{-1}$ with a range of -10.75 to $82.16 \mathrm{mmol} \mathrm{m}^{-2}$ day $^{-1}$ (Table 1). The average fluxes of $\mathrm{CH}_{4}$ and $\mathrm{N}_{2} \mathrm{O}$ were smaller, $2.32 \mathrm{mmol} \mathrm{m}^{-2}$ day $^{-1}$ (range 0.11-15.01) and $4.76 \mu \mathrm{mol} \mathrm{m}{ }^{-2} \mathrm{day}^{-1}$ (range 1.85-38.00), respectively. The average GWP for all lakes was $50.71 \mathrm{mmol} \mathrm{m}^{-2}$ day $^{-1}$ with a range of $6.39-207.85 \mathrm{mmol} \mathrm{m}^{-2}$ day $^{-1}$ (Fig. 5).

Unsurprisingly, despite the different wind fetches of the sampled lakes, the calculated emissions for $\mathrm{CH}_{4}, \mathrm{CO}_{2}$ and $\mathrm{N}_{2} \mathrm{O}$ (Fig. 5) closely matched the 
Fig. 4 Gas concentration in the surveyed lakes in Norway and Sweden. a Ar and $\mathrm{N}_{2}$ concentration, the dash line is saturation level; b $\mathrm{Ar}$ and $\mathrm{CO}_{2}$ concentration, the dash line is saturation level; c Negative correlation between $\mathrm{O}_{2}$ and $\mathrm{CO}_{2}$ concentration $\left(\mathrm{r}^{2}=0.24\right.$, $p<0.001)$, the solid line is the best-fit line; d Positive correlation between Arbased $\mathrm{O}_{2}$ deficit and $\mathrm{CO}_{2}$ concentration $\left(\mathrm{r}^{2}=0.57\right.$, $p<0.001)$, the dash line is $1: 1$ ratio, indicating that $1 \mathrm{~mol} \mathrm{O}_{2}$ was consumed to produce $1 \mathrm{~mol} \mathrm{CO}_{2}$. Unit of gas concentration is $\mu \mathrm{mol} \mathrm{L} \mathrm{L}^{-1}$
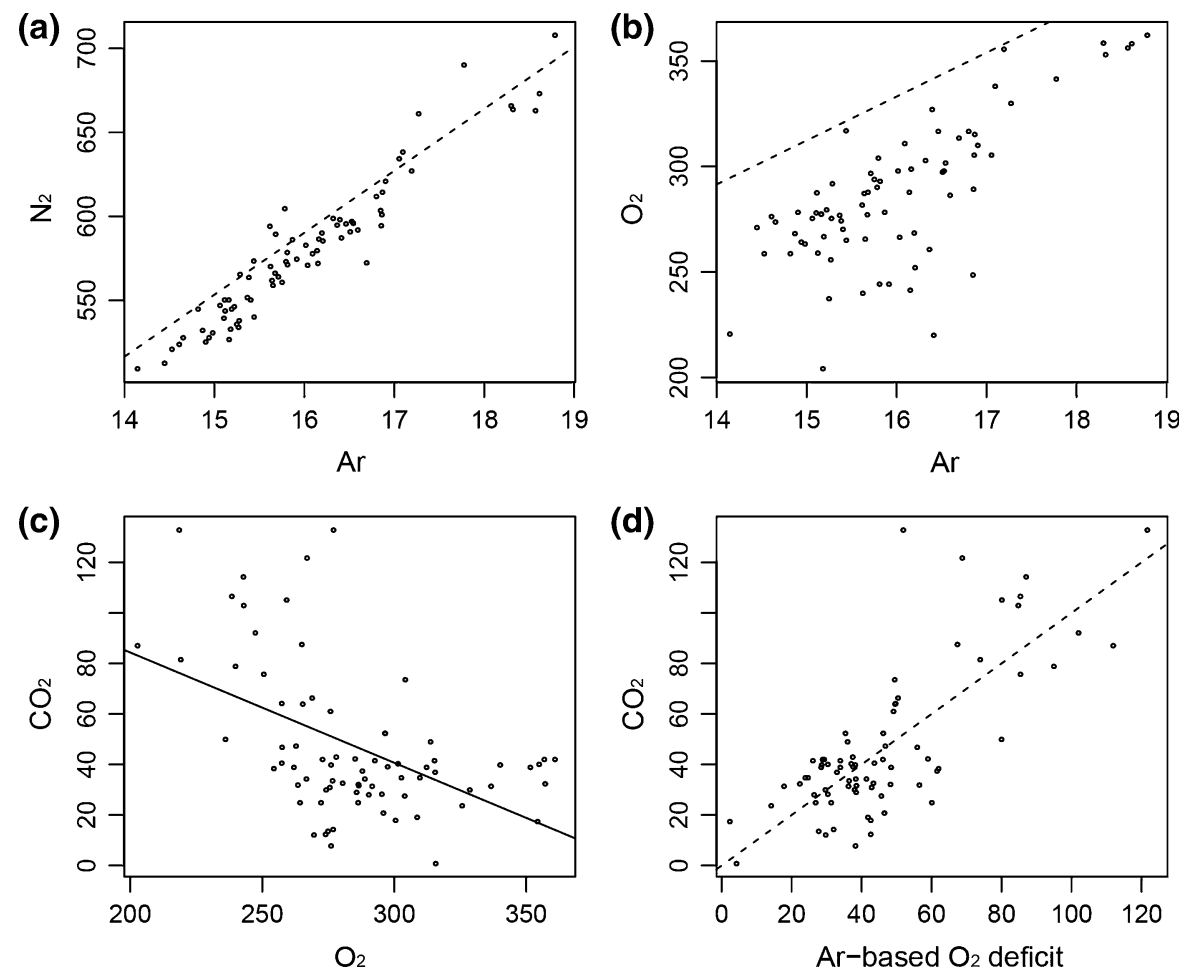

epilimnetic gas concentrations $\left(\mathrm{r}^{2}>0.85, p<0.001\right)$. Gas emissions have largely the same explanatory variables as gas concentrations.

GWP of these three GHGs across the lakes was best explained by TP $\left(\mathrm{r}^{2}=0.340, p<0.0001\right)$, Chl $a \quad\left(\mathrm{r}^{2}=0.202, \quad p<0.001\right), \quad$ TOC $\quad\left(\mathrm{r}^{2}=0.187\right.$, $p<0.001)$, followed by depth $\left(\mathrm{r}^{2}=0.109, p<0.01\right)$ and TN $\left(\mathrm{r}^{2}=0.104, p<0.01\right)$.

The spatial variation of GHG fluxes across the 75 lakes is shown in Fig. 5. When grouping the lakes in each two categories of size (area), TOC and TP, emissions of all measured GHGs and consequently also GWP were consistently higher in small lakes and lakes with high levels of TP and TOC.

\section{Discussion}

In this survey, very small lakes were avoided and sites were deliberately chosen to yield orthogonality of TOC and TP for estimating GHG emissions from lakes. Wind speed during the research period in the 75 lakes was below $5 \mathrm{~m} \mathrm{~s}^{-1}$ (see Supporting Information), therefore bubble injection, one of the possible factors influencing the gas exchange in the water-air interface, was considered negligible (Craig and Hayward 1987) and the use of the Cole and Caraco (1998) emission model was justified. This should minimize the role of confounding factors related to size and shape of lakes, and allow for more robust assessments of TOC and nutrients as drivers of GHG production and emissions. Furthermore, Ar-normalized saturation deficit/excess was used to assess the net metabolic changes since spring overturn.

We found that lakes with higher nutrient levels in general had higher emissions of $\mathrm{CO}_{2}$ and $\mathrm{CH}_{4}$ in accordance with Huttunen et al (2003a). Although Kankaala et al. (2013) did not report clear difference in $\mathrm{CO}_{2}$ flux between small lakes $\left(1-10 \mathrm{~km}^{2}\right)$ and large Finnish lakes $\left(10-50 \mathrm{~km}^{2}\right)$, their study showed that the smaller lakes $\left(<1 \mathrm{~km}^{2}\right)$ emitted more $\mathrm{CH}_{4}$ than larger (1-10 $\mathrm{km}^{2}$ ) lakes (Table 1). Other studies have reported higher emissions of both $\mathrm{CO}_{2}$ and $\mathrm{CH}_{4}$ in smaller lakes (Kortelainen et al. 2006b). Due to the low number of published data, it is difficult to compare $\mathrm{N}_{2} \mathrm{O}$ flux across the lakes with different sizes, nutrient levels, and TOC concentrations. While lake morphometry may be important (Huttunen et al. 2003b; Wang et al. 2006), our study clearly pointed to nutrient concentrations, and notably $\mathrm{N}$ as a major driver. This 


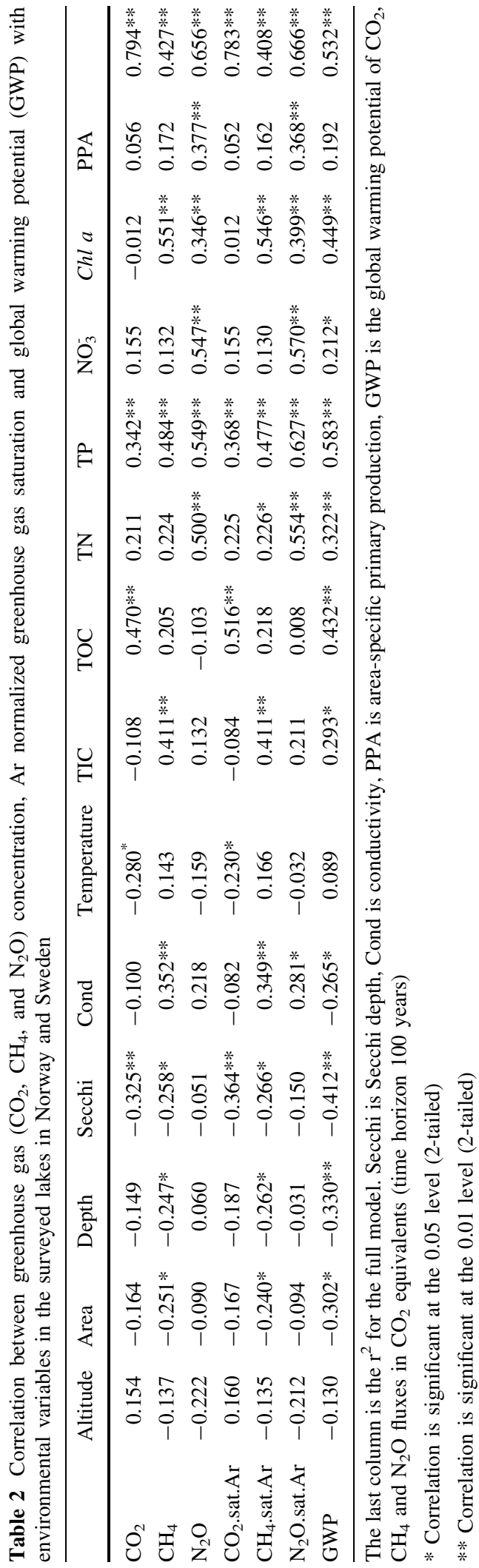

Fig. 5 Greenhouse gas fluxes from different types of the surveyed lakes in Norway and Sweden. $\mathbf{a}$ and $\mathbf{b}$ are $\mathrm{CO}_{2} ; \mathbf{c}$ and $\mathbf{d}$ are $\mathrm{CH}_{4} ; \mathbf{e}$ and $\mathbf{f}$ are $\mathrm{N}_{2} \mathrm{O} ; \mathbf{g}$ and $\mathbf{h}$ are the global warming potential (GWP). Lakes were divided into groups: small area $\left(<10 \mathrm{~km}^{2}\right)$ and large area $\left(>10 \mathrm{~km}^{2}\right)$; low TOC (<average $\left.6.25 \mathrm{mg} \mathrm{L}^{-1}\right)$ and high TOC $\left(>6.25 \mathrm{mg} \mathrm{L}^{-1}\right)$ divided by the mean concentration of TOC; oligotrophic (4-10 $\left.\mu \mathrm{g} \mathrm{L}^{-1} \mathrm{TP}\right)$ and mesotrophic (10-35 $\left.\mu \mathrm{g} \mathrm{L}^{-1} \mathrm{TP}\right)$ following OECD 1982. To compare greenhouse gas concentrations and emissions, the lakes were divided to groups according to area, TOC concentration and eutrophic levels. Lakes were divided to small (1-10 $\left.\mathrm{km}^{2}\right)$ and big (10-100 $\left.\mathrm{km}^{2}\right)$ lakes. The mean concentration of TOC was used as threshold to divide the lakes to two groups. Following the OECD classification of trophic state (OECD 1982), lakes were divided to oligotrophic (TP 4-10 $\mu \mathrm{g} \mathrm{L}^{-1}$ ) and mesotrophic (TP 10-35 $\mu \mathrm{g} \mathrm{L}^{-1}$ ) groups

is in support of studies pointing to elevated $\mathrm{N}$ deposition as a major driver of $\mathrm{N}_{2} \mathrm{O}$ emissions also from lakes (Kortelainen et al. 2013; McCrackin and Elser 2010).

Concentrations and Ar-normalized saturation for the various gases responded to the same parameters (Table 2). In terms of the surface $\mathrm{CO}_{2}$ concentrations, TOC was the main predictor, followed by TP. The degree of net heterotrophy, as reflected by $\mathrm{O}_{2}$ saturation deficit or $\mathrm{CO}_{2}$ super-saturation, was primarily related to TOC stimulating prokaryotic heterotroph activity while at the same time reducing autotrophic production due to light attenuation (slope of the $\mathrm{CO}_{2} /$ Ar-based $\mathrm{O}_{2}$ deficit relationship was 1.039, Fig. 4d). Unsurprisingly, $\mathrm{CO}_{2}$ concentrations correlated negatively with lake $\mathrm{pH}$ (only free $\mathrm{CO}_{2}$ was measured). It is rather striking that $\mathrm{CO}_{2}$ correlated positively with $\mathrm{TP}$, while TP had apparently no net impact on $\mathrm{O}_{2}$. TP may in this context play a dual role, both by promoting mineralization of TOC by heterotrophic bacteria and by promoting autotrophic production. Based on the relationship between $\mathrm{TP}$ and $\mathrm{O}_{2} \quad\left(\mathrm{r}^{2}=0.042\right.$, $p=0.076)$, TP may stimulate heterotrophic bacteria more than autotrophic plankton. Also the poor correlation between area-specific primary production and $\mathrm{CO}_{2}$ as well as $\mathrm{O}_{2}$ suggests a major role of catabolic processes (Cole et al. 1994; Hessen et al. 1990), photooxidation (Cory et al. 2014; Koehler et al. 2014), or inputs of exogenous $\mathrm{CO}_{2}$, such as from groundwater (Öquist et al. 2009).

Surface $\mathrm{CH}_{4}$ concentrations across lakes were mainly governed by TP and Chl $a$, suggesting the importance of lake productivity for the $\mathrm{CH}_{4}$ 
(a)

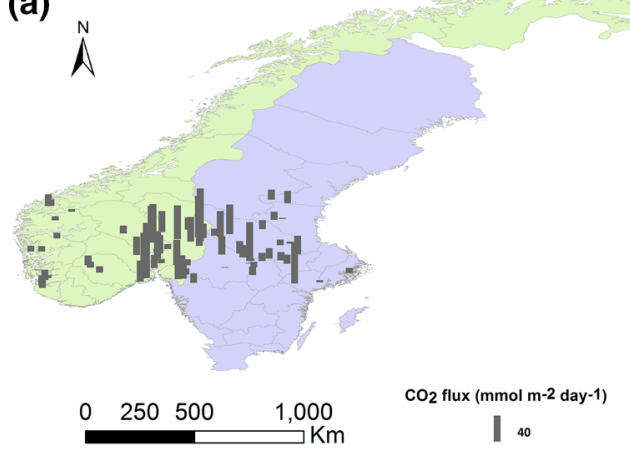

(c)

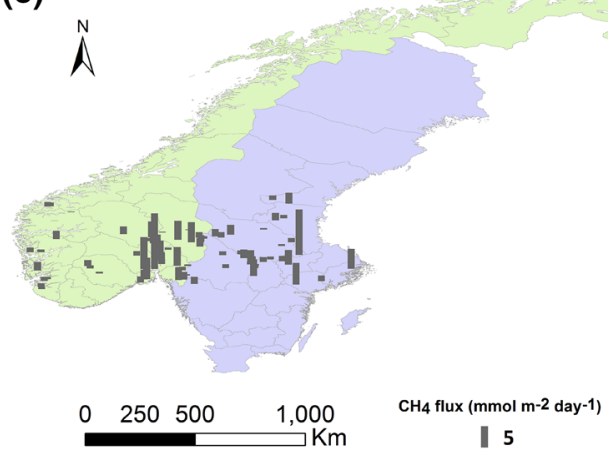

(e)

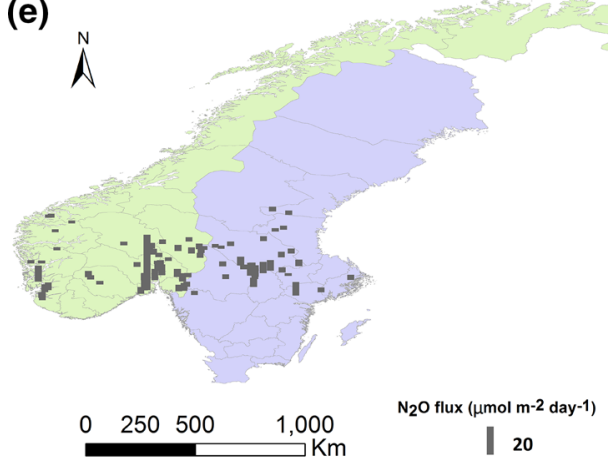

(g)

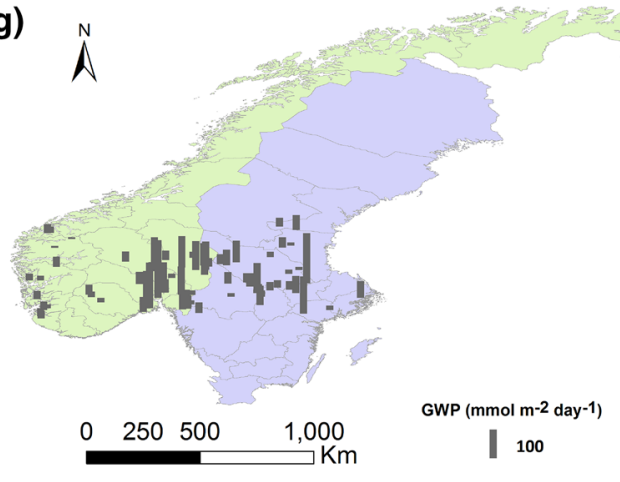

(b)

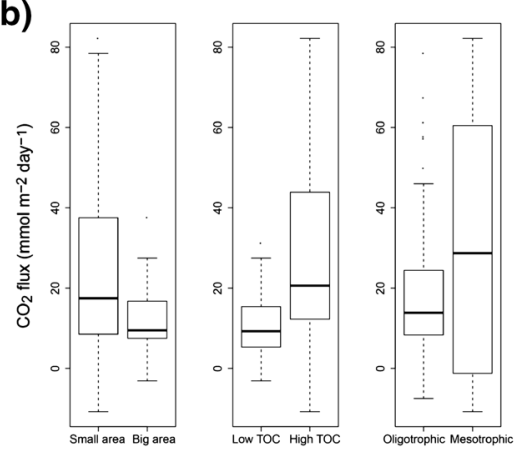

(d)

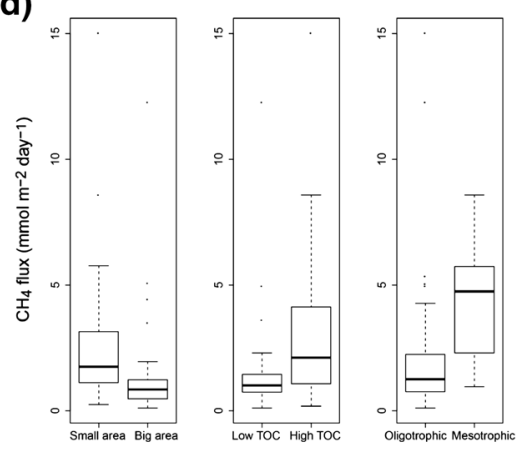

(f)

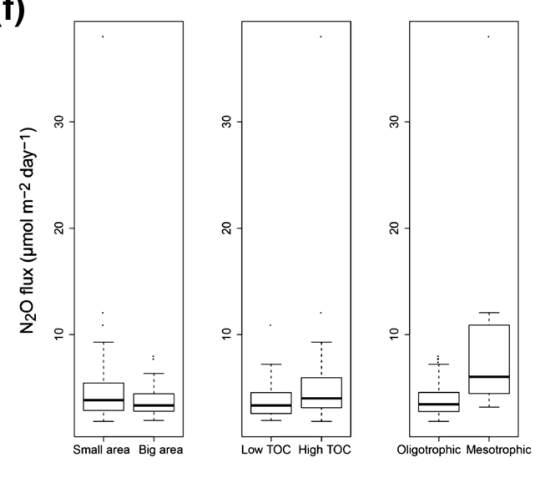

(h)
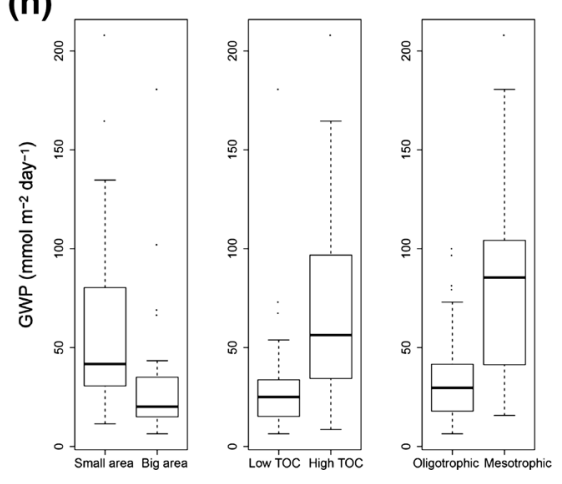
concentrations. TP is the nutrient which usually limits the primary production in oligotrophic and mesotrophic boreal lakes (e.g. Nurnberg and Shaw 1998). High phytoplankton production can supply bioavailable organic matter to the sediment, thus supporting methanogenesis and production of $\mathrm{CH}_{4}$. Studies found that the fresh organic $\mathrm{C}$ from primary production and flooded previous biomass has a greater contribution than old peat deposits to $\mathrm{CH}_{4}$ production in some boreal waters (Huttunen et al. 2002; Kelly et al. 1997).

Similar as with $\mathrm{CH}_{4}$ concentrations, surface $\mathrm{N}_{2} \mathrm{O}$ concentrations were best explained by TP and Chl $a$, indicating importance of autotroph production for these gases. Also, nitrogen (total $\mathrm{N}_{\text {and }} \mathrm{NO}_{3}{ }^{-}$) was a strong contributor to $\mathrm{N}_{2} \mathrm{O}$. TN is partly on organic form as DOM, while $\mathrm{NO}_{3}{ }^{-}$is closely related to atmospheric $\mathrm{N}$ deposition in these pristine lakes (Hessen et al. 2009).

The key roles of lake morphometry and catchment properties for GHG concentrations and emissions have been verified for several boreal lakes (Kankaala et al. 2013; Read et al. 2012). It is noteworthy that neither of the physical properties including altitude, area and depth of the lakes were major determinants of the GHG concentrations and fluxes, despite a trend for higher production and emission in smaller lakes. This likely reflects the fact that very small and sheltered lakes were avoided in this study, and hence that geographical and morphological variability was minor relative to the gradients in TOC and TP.

TOC concentration typically reflect the proportion of forest, bogs and wetlands within the catchment, and is generally one of the main sources of dissolved $\mathrm{CO}_{2}$ (Humborg et al. 2010; Kortelainen 1993; Larsen et al. 2011b; Larsen et al. 2011c; Sobek et al. 2003). This is partly attributed to bacterial mineralization (del Giorgio and Peters 1994; Hessen et al. 1990) or photooxidation (Cory et al. 2014; Koehler et al. 2014), both processes typically generating supersaturation in boreal lakes and thus net release of $\mathrm{CO}_{2}$ (Cole et al. 1994). Inputs of exogenous $\mathrm{CO}_{2}$ (i.e. from groundwater) could also contribute substantially to $\mathrm{CO}_{2}$ in the water column (Humborg et al. 2010; Öquist et al. 2009) and also be one of the causes for decoupling between $\mathrm{CO}_{2}$ and $\mathrm{O}_{2}$ concentrations. Most studies identified TOC also as a major driver of dissolved $\mathrm{CH}_{4}$, yet often lake productivity, lake area, water column stability or ionic strength serve as key predictors (Hessen and Nygaard 1992; Juutinen et al.
2009; Kankaala et al. 2013; Sobek et al. 2003; Xing et al. 2006). In fact, for lakes in general, productivity and deep-water anoxia seem most important, while TOC is more important for $\mathrm{CO}_{2}$ concentrations and fluxes in small and sheltered lakes.

A key issue in boreal areas is how the observed increase in terrestrially derived DOM (i.e. lake "browning"), either being caused by reduced $\mathrm{SO}_{4}$ deposition (Monteith et al. 2007) on a decadal scale or by long term changes in vegetation density (Larsen et al. 2011a), will affect lake productivity and hence GHG concentrations and emissions. While browning doubtlessly will increase concentrations and fluxes of $\mathrm{CO}_{2}$, the net effect on $\mathrm{CH}_{4}$ is less clear. In boreal, pristine lakes, terrestrially derived DOM is the key source of TOC, as well as of P and N. TOC will decrease primary production owing to increased light attenuation (Thrane et al. 2014), but increase the likelihood of epilimnetic anoxia and thus support methanogenic activity (Bastviken et al. 2004a), hence the net effect of browning on $\mathrm{CH}_{4}$ is likely positive. For $\mathrm{N}_{2} \mathrm{O}$, it is first and foremost high (or elevated) levels of $\mathrm{N}$ inputs that will promote increased emissions, and given the widespread impacts of increased $\mathrm{N}$ deposition on lake ecosystems (Elser et al. 2009; McCrackin and Elser 2011), the coupling of climate, TOC and N deposition for GHG-emissions is a topic that warrants further attention. Advancing our understanding of lake browning in terms of global warming (GWP, i.e. the combined effect of $\mathrm{CO}_{2}, \mathrm{CH}_{4}$ and $\mathrm{N}_{2} \mathrm{O}$ ) is challenging but adds a new perspective to limnetic responses to future climate change. The highly significant correlation between TOC and GWP in our study suggests that the GWP will very likely increase with water browning in boreal area.

The current study is based on a single integrated sample from a large number of remote lakes, sampled by hydroplane. Due to diurnal and seasonal variation of gas flux (e.g. Natchimuthu et al. 2014; Xing et al. 2004), the scope of this study was not to calculate the annual flux of GHG (which then would have been achievable for a limited number of lakes only), but rather using Ar as the proxy for net metabolic changes from spring overturn to mid-summer, and their relationship to ambient parameters. Better insight in the drivers of both absolute and relative rates of change may serve an important input to models of future GHG emissions from boreal lakes. 
Acknowledgement This work was funded by the Research Council of Norway: COMSAT Grant 196336/S30, BiWA Grant 221410 and ECCO Grant 224779. We thank Hilde Haakenstad at Norwegian Meteorological Institute for the provision of the NORA10 data. Two anonymous referees and the editor are gratefully acknowledged.

Open Access This article is distributed under the terms of the Creative Commons Attribution 4.0 International License (http:// creativecommons.org/licenses/by/4.0/), which permits unrestricted use, distribution, and reproduction in any medium, provided you give appropriate credit to the original author(s) and the source, provide a link to the Creative Commons license, and indicate if changes were made.

\section{References}

Aeschbach-Hertig W, Peeters F, Beyerle U, Kipfer R (1999) Interpretation of dissolved atmospheric noble gases in natural waters. Water Resour Res 35(9):2779-2792

Bastviken D, Cole J, Pace M, Tranvik L (2004a) Methane emissions from lakes: dependence of lake characteristics, two regional assessments, and a global estimate. Glob Bioegochem Cycles 18(4):GB4009. doi:10.1029/ 2004GB002238

Bastviken D, Persson L, Odham G, Tranvik L (2004b) Degradation of dissolved organic matter in oxic and anoxic lake water. Limnol Oceanogr 49(1):109-116. doi:10.4319/lo. 2004.49.1.0109

Bastviken D, Tranvik LJ, Downing JA, Crill PM, Enrich-Prast A (2011) Freshwater methane emissions offset the continental carbon sink. Science 331(6013):50. doi:10.1126/ science. 1196808

Berggren M, Laudon H, Jansson M (2009) Aging of allochthonous organic carbon regulates bacterial production in unproductive boreal lakes. Limnol Oceanogr 54(4):1333-1342

Casper P, Maberly SC, Hall GH, Finlay BJ (2000) Fluxes of methane and carbon dioxide from a small productive lake to the atmosphere. Biogeochemistry 49(1):1-19

Cole JJ, Caraco NF (1998) Atmospheric exchange of carbon dioxide in a low-wind oligotrophic lake measured by the addition of $\mathrm{SF}_{6}$. Limnol Oceanogr 43(4):647-656. doi:10. 4319/1o.1998.43.4.0647

Cole JJ, Caraco NF, Kling GW, Kratz TK (1994) Carbon dioxide supersaturation in the surface waters of lakes. Science 265(5178):1568-1570. doi:10.1126/science.265. 5178.1568

Core Team R (2014) R: a language and environment for statistical computing. R Foundation for Statistical Computing, Vienna

Cory RM, Ward CP, Crump BC, Kling GW (2014) Sunlight controls water column processing of carbon in arctic fresh waters. Science 345(6199):925-928. doi:10.1126/science. 1253119

Craig H, Hayward T (1987) Oxygen supersaturation in the ocean: Biological versus physical contributions. Science 235(4785):199-202. doi:10.1126/science.235.4785.199
Craig H, Wharton RA, Mckay CP (1992) Oxygen supersaturation in ice-covered Antarctic lakes-Biological versus physical contributions. Science 255(5042):318-321. doi:10.1126/science.11539819

del Giorgio PA, Peters RH (1994) Patterns in planktonic P: R ratios in lakes: influence of lake trophy and dissolved organic-carbon. Limnol Oceanogr 39(4):772-787. doi:10. 4319/lo.1994.39.4.0772

Demarty M, Bastien J, Tremblay A (2011) Annual follow-up of gross diffusive carbon dioxide and methane emissions from a boreal reservoir and two nearby lakes in Québec, Canada. Biogeosciences 8(1):41-53. doi:10.5194/bg-8-41-2011

Elser JJ, Andersen T, Baron JS, Bergstrom AK, Jansson M, Kyle M, Nydick KR, Steger L, Hessen DO (2009) Shifts in lake N: $\mathrm{P}$ stoichiometry and nutrient limitation driven by atmospheric nitrogen deposition. Science 326(5954):835-837. doi:10.1126/science.1176199

Henriksen A, Skjelvåle BL, Mannio J, Wilander A, Harriman R, Curtis C, Jensen JP, Fjeld E, Moiseenko T (1998) Northern European lake survey, 1995: Finland, Norway, Sweden, Denmark, Russian Kola, Russian Karelia, Scotland and Wales. Ambio 27(2):80-91.

Hessen D, Nygaard K (1992) Bacterial transfer of methane and detritus; implications for the pelagic carbon budget and gaseous release. Arch Hydrobiol Beih Ergebn Limnol 37:139-148

Hessen DO, Andersen T, Larsen S, Skjelkvale BL, de Wit HA (2009) Nitrogen deposition, catchment productivity, and climate as determinants of lake stoichiometry. Limnol Oceanogr 54(6):2520-2528. doi:10.4319/1o.2009.54.6_ part_2.2520

Hessen DO, Andersen T, Lyche A (1990) Carbon metabolism in a humic lake: pool sizes and cycling through zooplankton. Limnol Oceanogr 35(1):84-99. doi:10.4319/lo.1990.35.1. 0084

Humborg C, Morth CM, Sundbom M, Borg H, Blenckner T, Giesler R, Ittekkot V (2010) $\mathrm{CO}_{2}$ supersaturation along the aquatic conduit in Swedish watersheds as constrained by terrestrial respiration, aquatic respiration and weathering. Glob Chang Biol 16(7):1966-1978. doi:10.1111/j.13652486.2009.02092.x

Huttunen JT, Alm J, Liikanen A, Juutinen S, Larmola T, Hammar T, Silvola J, Martikainen PJ (2003a) Fluxes of methane, carbon dioxide and nitrous oxide in boreal lakes and potential anthropogenic effects on the aquatic greenhouse gas emissions. Chemosphere 52(3):609-621. doi:10. 1016/s0045-6535(03)00243-1

Huttunen JT, Juutinen S, Alm J, Larmola T, Hammar T, Silvola J, Martikainen PJ (2003b) Nitrous oxide flux to the atmosphere from the littoral zone of a boreal lake. J Geophys Res Atmos 108:D14. doi:10.1029/2002JD002989

Huttunen JT, Vaisanen TS, Hellsten SK, Heikkinen M, Nykanen $\mathrm{H}$, Jungner H, Niskanen A, Virtanen MO, Lindqvist OV, Nenonen OS, Martikainen PJ (2002) Fluxes of $\mathrm{CH}_{4}, \mathrm{CO}_{2}$, and $\mathrm{N}_{2} \mathrm{O}$ in hydroelectric reservoirs Lokka and Porttipahta in the northern boreal zone in Finland. Glob Bioegochem Cycles 16(1):3

Jansson M, Persson L, De Roos AM, Jones RI, Tranvik LJ (2007) Terrestrial carbon and intraspecific size-variation shape lake ecosystems. Trends Ecol Evol 22(6):316-322. doi:10.1016/j.tree.2007.02.015 
Johnson M (2010) A numerical scheme to calculate temperature and salinity dependent air-water transfer velocities for any gas. Ocean Sci 6(4):913-932. doi:10.5194/os-6-913-2010

Jones SE, Solomon CT, Weidel BC (2012) Subsidy or subtraction: how do terrestrial inputs influence consumer production in lakes? Freshw Rev 5(1):37-49

Juutinen S, Rantakari M, Kortelainen P, Huttunen JT, Larmola T, Alm J, Silvola J, Martikainen PJ (2009) Methane dynamics in different boreal lake types. Biogeosciences 6(2):209-223. doi:10.5194/bg-6-209-2009

Kankaala P, Huotari J, Tulonen T, Ojala A (2013) Lake-size dependent physical forcing drives carbon dioxide and methane effluxes from lakes in a boreal landscape. Limnol Oceanogr 58(6):1915-1930. doi:10.4319/lo.2013.58.6. 1915

Kelly CA, Rudd JWM, Bodaly RA, Roulet NP, StLouis VL, Heyes A, Moore TR, Schiff S, Aravena R, Scott KJ, Dyck B, Harris R, Warner B, Edwards G (1997) Increases in fluxes of greenhouse gases and methyl mercury following flooding of an experimental reservoir. Environ Sci Technol 31(5):1334-1344

Kling GW, Kipphut GW, Miller MC (1992) The flux of $\mathrm{CO}_{2}$ and $\mathrm{CH}_{4}$ from lakes and rivers in arctic Alaska. Hydrobiologia 240(1-3):23-36

Koehler B, Landelius T, Weyhenmeyer GA, Machida N, Tranvik LJ (2014) Sunlight-induced carbon dioxide emissions from inland waters. Glob Bioegochem Cycle 28(7):696-711. doi:10.1002/2014GB004850

Kortelainen P (1993) Content of total organic-carbon in Finnish lakes and its relationship to catchment characteristics. Can J Fish Aquat Sci 50(7):1477-1483. doi:10.1139/f93-168

Kortelainen P, Mattsson T, Finér L, Ahtiainen M, Saukkonen S, Sallantaus T (2006a) Controls on the export of C, N, P and $\mathrm{Fe}$ from undisturbed boreal catchments, Finland. Aquat Sci 68(4):453-468. doi:10.1007/s00027-006-0833-6

Kortelainen P, Rantakari M, Huttunen JT, Mattsson T, Alm J, Juutinen S, Larmola T, Silvola J, Martikainen PJ (2006b) Sediment respiration and lake trophic state are important predictors of large $\mathrm{CO}_{2}$ evasion from small boreal lakes. Glob Chang Biol 12(8):1554-1567. doi:10.1111/j.13652486.2006.01167.x

Kortelainen P, Rantakari M, Pajunen H, Huttunen JT, Mattsson T, Juutinen S, Larmola T, Alm J, Silvola J, Martikainen PJ (2013) Carbon evasion/accumulation ratio in boreal lakes is linked to nitrogen. Glob Bioegochem Cycle 27(2):363-374. doi:10.1002/gbc.20036

Larmola T, Alm J, Juutinen S, Huttunen JT, Martikainen PJ, Silvola J (2004) Contribution of vegetated littoral zone to winter fluxes of carbon dioxide and methane from boreal lakes. J Geophys Res 109(D19)

Larsen S, Andersen T, Hessen DO (2011a) Climate change predicted to cause severe increase of organic carbon in lakes. Global Change Biol 17(2):1186-1192. doi:10.1111/ j.1365-2486.2010.02257.x

Larsen S, Andersen T, Hessen DO (2011b) The $\mathrm{pCO}_{2}$ in boreal lakes: Organic carbon as a universal predictor? Glob Bioegochem Cycles 25:GB2012. doi:10.1029/2010GB003864

Larsen S, Andersen T, Hessen DO (2011b) Predicting organic carbon in lakes from climate drivers and catchment properties. Glob Bioegochem Cycles 25:GB3007. doi:10.1029/ 2010GB003908
Lemon E, Lemon D (1981) Nitrous oxide in freshwaters of the Great Lakes Basin. Limnol Oceanogr 26:867-879. doi:10. 4319/lo.1981.26.5.0867

Liikanen A, Huttunen JT, Murtoniemi T, Tanskanen H, Vaisanen T, Silvola J, Alm J, Martikainen PJ (2003) Spatial and seasonal variation in greenhouse gas and nutrient dynamics and their interactions in the sediments of a boreal eutrophic lake. Biogeochemistry 65(1):83-103

McCrackin ML, Elser JJ (2010) Atmospheric nitrogen deposition influences denitrification and nitrous oxide production in lakes. Ecology 91(2):528-539. doi:10.1890/08-2210.1

McCrackin ML, Elser JJ (2011) Greenhouse gas dynamics in lakes receiving atmospheric nitrogen deposition. Glob Bioegochem Cycle 25:GB4005. doi:10.1029/2010GB003897

McDonald CP, Stets EG, Striegl RG, Butman D (2013) Inorganic carbon loading as a primary driver of dissolved carbon dioxide concentrations in the lakes and reservoirs of the contiguous United States. Glob Bioegochem Cycles 27(2):285-295. doi:10.1002/gbc.20032

Monteith DT, Stoddard JL, Evans CD, de Wit HA, Forsius M, Hogasen T, Wilander A, Skjelkvale BL, Jeffries DS, Vuorenmaa J, Keller B, Kopacek J, Vesely J (2007) Dissolved organic carbon trends resulting from changes in atmospheric deposition chemistry. Nature 450(7169):537U9. doi:10.1038/nature06316

Molstad L, Dörsch P, Bakken LR (2007) Robotized incubation system for monitoring gases $\left(\mathrm{O}_{2}, \mathrm{NO}, \mathrm{N}_{2} \mathrm{O}, \mathrm{N}_{2}\right)$ in denitrifying cultures. J Microbiol Meth 71(3):202-211

Myhre G, Shindell D, Bréon F, Collins W, Fuglestvedt J, Huang J, Koch D, Lamarque J, Lee D, Mendoza B, Nnkajima T, Robock A, Stephens G, Takemura T, Zhang H (2013) Anthropogenic and natural radiative forcing. In: T Stocker, F, D Qin, G-K Plattner, M Tignor, S Allen, K, J Boschung, A Nauels, Y Xia, V Bex, P Midgley, M (eds) Climate Change 2013: the physical science basis contribution of working group I to the Fifth Assessment Report of the Intergovernmental Panel on Climate Change. Cambridge University Press, Cambridge, UK and New York, USA, pp 659-740

Natchimuthu S, Selvam BP, Bastviken D (2014) Influence of weather variables on methane and carbon dioxide flux from a shallow pond. Biogeochemistry 119(1-3):403-413

Nurnberg GK, Shaw M (1998) Productivity of clear and humic lakes: nutrients, phytoplankton, bacteria. Hydrobiologia 382:97-112

OECD (1982) Eutrophication of waters. Monitoring assessment and control. OECD Cooperative Programme on Monitoring of Inland Waters (Eutrophication Control), Environment Directorate, OECD, Paris

Ojala A, Bellido JL, Tulonen T, Kankaala P, Huotari J (2011) Carbon gas fluxes from a brown-water and a clear-water lake in the boreal zone during a summer with extreme rain events. Limnol Oceanogr 56(1):61-76. doi:10.4319/lo. 2011.56.1.0061

Öquist MG, Wallin M, Seibert J, Bishop K, Laudon H (2009) Dissolved inorganic carbon export across the soil/stream interface and its fate in a Boreal headwater stream. Environ Sci Technol 43(19):7364-7369

Peeters F, Kipfer R, Hohmann R, Hofer M, Imboden DM, Kodenev GG, Khozder T (1997) Modeling transport rates in Lake Baikal: gas exchange and deep water renewal. Environ Sci Technol 31(10):2973-2982 
Raymond PA, Hartmann J, Lauerwald R, Sobek S, McDonald C, Hoover M, Butman D, Striegl R, Mayorga E, Humborg C (2013) Global carbon dioxide emissions from inland waters. Nature 503(7476):355-359

Read JS, Hamilton DP, Desai AR, Rose KC, MacIntyre S, Lenters JD, Smyth RL, Hanson PC, Cole JJ, Staehr PA, Rusak JA, Pierson DC, Brookes JD, Laas A, Wu CH (2012) Lake-size dependency of wind shear and convection as controls on gas exchange. Geophys Res Lett 39:L09405. doi:10.1029/2012GL051886

Riera JL, Schindler JE, Kratz TK (1999) Seasonal dynamics of carbon dioxide and methane in two clear-water lakes and two bog lakes in northern Wisconsin, USA. Can J Fish Aquat Sci 56(2):265-274

Schwarz JIK, Eckert W, Conrad R (2008) Response of the methanogenic microbial community of a profundal lake sediment (Lake Kinneret, Israel) to algal deposition. Limnol Oceanogr 53(1):113-121

Schwarzenbach RP, Gschwend PM, Imboden DM (2005) Environmental organic chemistry. Wiley, New York

Seekell DA, Lapierre JF, Ask J, Bergström AK, Deininger A, Rodríguez P, Karlsson J (2015) The influence of dissolved organic carbon on primary production in northern lakes. Limnol Oceanogr 60:1276-1285

Sobek S, Algesten G, Bergstrom AK, Jansson M, Tranvik LJ (2003) The catchment and climate regulation of $\mathrm{pCO}(2)$ in boreal lakes. Glob Chang Biol 9(4):630-641. doi:10.1046/ j.1365-2486.2003.00619.x

Sobek S, Tranvik LJ, Prairie YT, Kortelainen P, Cole JJ (2007) Patterns and regulation of dissolved organic carbon: an analysis of 7,500 widely distributed lakes. Limnol Oceanogr 52(3):1208-1219. doi:10.4319/lo.2007.52.3.1208

Solheim AL, Rekolainen S, Moe SJ, Carvalho L, Phillips G, Ptacnik R, Penning WE, Toth LG, O'Toole C, Schartau A-KL (2008) Ecological threshold responses in European lakes and their applicability for the water framework directive (WFD) implementation: synthesis of lakes results from the REBECCA project. Aquat Ecol 42(2):317-334. doi:10.1007/s10452-008-9188-5

Thrane J-E, Hessen DO, Andersen T (2014) The absorption of light in lakes: Negative impact of dissolved organic carbon on primary productivity. Ecosystems 17:1040-1052. doi:10.1007/s10021-014-9776-2

Tomonaga Y, Blättler R, Brennwald MS, Kipfer R (2012) Interpreting noble-gas concentrations as proxies for salinity and temperature in the world's largest soda lake (Lake Van, Turkey). J Asian Earth Sci 59:99-107. doi:10.1016/j. jseaes.2012.05.011

Tranvik LJ, Downing JA, Cotner JB, Loiselle SA, Striegl RG, Ballatore TJ, Dillon P, Finlay K, Fortino K, Knoll LB
(2009) Lakes and reservoirs as regulators of carbon cycling and climate. Limnol Oceanogr 54(6):2298-2314. doi:10. 4319/lo.2009.54.6_part_2.2298

Tremblay A, Therrien J, Hamlin B, Wichmann E, LeDrew LJ (2005) GHG emissions from boreal reservoirs and natural aquatic ecosystems. In: Tremblay A, Varfalvy L, Roehm C, Garneau M (eds) Greenhouse gas emissions: fluxes and processes hydroelectric reservoirs and natural environments. Springer, Berlin, pp 209-232

Wang HJ, Wang WD, Yin CQ, Wang YC, Lu JW (2006) Littoral zones as the "hotspots" of nitrous oxide $\left(\mathrm{N}_{2} \mathrm{O}\right)$ emission in a hyper-eutrophic lake in China. Atmos Environ 40(28):5522-5527. doi:10.1016/j.atmosenv.2006.05.032

Wanninkhof R (1992) Relationship between wind speed and gas exchange over the ocean. J Geophys Res Ocean 97:7373-7382. doi:10.1029/92JC00188

West WE, Coloso JJ, Jones SE (2012) Effects of algal and terrestrial carbon on methane production rates and methanogen community structure in a temperate lake sediment. Freshw Biol 57(5):949-955

Wilhelm E, Battino R, Wilcock RJ (1977) Low-pressure solubility of gases in liquid water. Chem Rev 77(2):219-262. doi:10.1021/cr60306a003

Wilkinson GM, Cole JJ, Pace ML, Johnson RA, Kleinhans MJ (2015) Physical and biological contributions to metalimnetic oxygen maxima in lakes. Limnol Oceanogr 60(1):242-251. doi:10.1002/lno.10022

Xing YP, Xie P, Yang H, Ni LY, Wang YS, Rong KW (2005) Methane and carbon dioxide fluxes from a shallow hypereutrophic subtropical Lake in China. Atmos Environ 39(30):5532-5540

Xing YP, Xie P, Yang H, Ni LY, Wang YS, Tang WH (2004) Diel variation of methane fluxes in summer in a eutrophic subtropical lake in China. J Freshw Ecol 19(4):639-644. doi:10.1080/02705060.2004.9664745

Xing YP, Xie P, Yang H, Wu AP, Ni LY (2006) The change of gaseous carbon fluxes following the switch of dominant producers from macrophytes to algae in a shallow subtropical lake of China. Atmos Environ 40(40):8034-8043. doi:10.1016/j.atmosenv.2006.05.033

Yang H, Xie P, Ni LY, Fower RJ (2011) Underestimation of $\mathrm{CH}_{4}$ emission from freshwater lakes in China. Environ Sci Technol 45(10):4203-4204. doi:10.1021/es2010336

Yang H, Xing YP, Xie P, Ni LY, Rong KW (2008) Carbon source/sink function of a subtropical, eutrophic lake determined from an overall mass balance and a gas exchange and carbon burial balance. Environ Pollut 151(3):559-568. doi:10.1016/j.envpol.2007.04.006 